case should be subject to criminal prosecution, or the imposition of penalties under the market abuse provisions.

No guidance from the Treasury has, however, as yet been published, although this may simply be due to the fact that the new regime will not come into force until next year. In any case, the question arises as to what extent this guidance will be legally binding: if it is mere guidance, the FSA (who will have the power to bring prosecutions for insider dealing) or the Crown Prosecution Service may be free to disregard it. The general assumption that no one could ever both be prosecuted and suffer the imposition of civil fines is a dangerous one. In France, for example, insider dealing is, as in the UK, prohibited under both the criminal law (Article 10-1 of Ordinance 67-833 of 28 September 1967 (as amended)) and an administrative regulation (COB Regulation 90-08). It is rare for a given case to be dealt with and punished under both provisions, but it has been known, notably in the case of
Delalande/Synthélabo, in which a director through insider dealing made a profit estimated at FF69.5m (approx. $£ 7 \mathrm{~m}$ ). Following proceedings under the $\mathrm{COB}$ regulation, in which he was fined the maximum penalty of FF10m (approx. $£ 1 \mathrm{~m}$ ), the director was then also prosecuted under the Ordinance. Although, in the event, the court imposed no further penalty other than to order that he pay the costs of the hearing, the principle had clearly been established that regulatory proceedings of this type do not automatically rule out a criminal prosecution. Since the FSA is arguably a unitary authority modelled on those of other jurisdictions, such as the $\mathrm{COB}$, it may well be that in time such principles are adopted in the UK as well.

Clause 99 of the Bill requires the FSA to publish a statement of its policy in relation to the imposition of penalties for market abuse. Sub-clause (2) makes clear, however, that the FSA is empowered to alter or replace that policy should it see fit, although if it does so it must publish the replacement or alterations. It is not clear, however, what redress a person fined by the FSA other than under the published policy would have. There would arguably be grounds for judicial review on the basis that, whether or not it was actually illegal, it might be unreasonable for the FSA, having published a policy in accordance with its legal obligations, then to depart from it. Nevertheless the possibility cannot be ruled out that the Divisional Court might be less than sympathetic to a person who had recently been convicted of insider dealing or misleading investors.

To conclude, much remains unclear at this stage. It may well be that only a series of test cases will ultimately show the extent to which criminal prosecutions and civil fines may run in parallel.

Peter Richards-Carpenter

Head of Financial Services, Rowe \& Maw

\title{
European Law
}

\section{Medicinal products and essential similarity: the preliminary ruling in R v Medicines Control Agency ex parte Generics}

\section{by Frank Wooldridge}

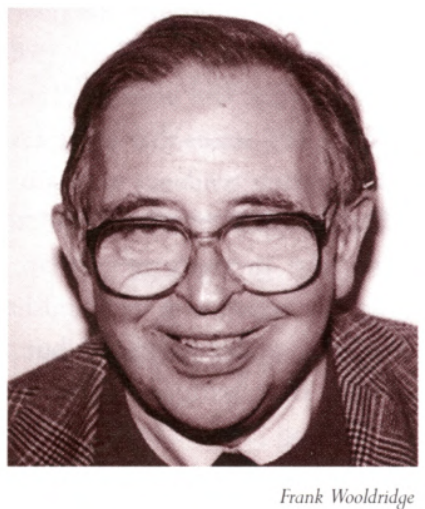

The Community legislation concerning the authorisation of medicinal products is of considerable complexity. However, the European Court of Justice (ECJ) has recently elucidated the controversial meaning of the concept of 'essential similarity' in its recent decision in $R_{V}$ Medicines Control Agency ex parte Generics
(Case C-368/96, not yet reported). It will be impossible to understand this ruling without some elementary understanding of the relevant provisions of the applicable Community legislation.

According to Council Regulation 2309/93 (OJ 1993 L214/1), authorisations of certain medicinal products must take place at Community level. Other such products require authorisation by the competent authority of the relevant member state (in this case the Licensing Authority established by the Medicines Act 1968, acting by means of the Medicines Control Agency) before they can be marketed, in accordance with the provisions of Council Directive 65/65 (OJ 1965-1966, Eng. Spec. Ed., p. 20), subsequently amended by Council Directive 75/318 (OJ 1975 L147/1),
Council Directive 87/21 (OJ 1987 115/36), Council Directive 93/39 (OJ 1993 L214/22) and Commission Regulation 541/95 (OJ 1995 L55/7).

An application for authorisation is required by art. $4(2) .8$ of Council Directive 65/65/ (as amended) to be accompanied by the results of certain tests and clinical trials (which generally involve the use of humans or animals). However, the applicant is not required to provide the results of pharmacological and toxicological tests or the results of clinical trials under three circumstances. Thus, art. 4(2).8(a)(iii) provides that such results are not required if the applicant can demonstrate that the product is essentially similar to one which has already been authorised within the Community for six or ten years and 
which is marketed in the member state in which the application is made. (The period is extended to ten years for certain high technology medicinal products, and member states have a discretion to extend the period to ten years for all products marketed on their territory. The UK has availed itself of this option.) This abridged procedure enables a second applicant for marketing authorisation for a particular product to save the time and expense necessary in order to gather the pharmacological, toxicological and clinical data. It also avoids, on public policy grounds, the repetition of tests on humans or animals where not absolutely necessary.

Large pharmaceutical companies often spend very considerable amounts on research, and this is sometimes reflected in changes to the medicinal product which give rise to changes in marketing authorisations. Annex II to Commission Regulation 541/95 provides that certain changes to a marketing authorisation are to be considered as fundamentally altering the terms of that authorisation and therefore require an application for a new marketing authorisation to be made rather than merely an application to vary the terms of the marketing authorisation. Among the changes which require such a new application are, inter alia, the addition of an indication in a different therapeutic area, the addition of a new strength and the addition of a new route of administration.

\section{FACTS}

The principal litigation in the case annotated consisted of applications for judicial review of decisions made by the Medicines Control Agency in the context of applications for authorisation under the abridged procedure governed by art. 4(2).8(a) of Directive 65/65, as amended, by generics distributors and manufacturers. The pharmaceutical companies - Squibb, Wellcome and Glaxo - contended that an essentially similar medicinal product should only be granted a marketing authorisation under the abridged procedure for indications which had been authorised in any member state for six or ten years. The generics companies (Generics and Gea) took the different view that such authorisations should be granted in respect of all indications, dosage forms, or dosage schedules currently authorised for the relevant product of the date of the application under art. 4(2).8(a)(iii), irrespective of whether they had been authorised for at least six or ten years.

\section{QUESTIONS REFERRED UNDER ART. 177}

The Queens Bench Division referred five questions to the ECJ for a preliminary ruling under art. 177 (art. 234, post Amsterdam). The most detailed of these questions were the first three.

The first question was principally concerned with the meaning of the phrase 'essentially similar' in art. 4(2).8(a)(iii) of Council Directive 65/65, as amended, and whether the competent authority of a member state has any margin of discretion in determining the criteria according to which the essential similarity of two different products is to be judged.

The second and third questions concerned in essence what therapeutic indications and dosage schedules might be authorised under the abridged procedure provided for in art. 4(2).8(a)(iii) of Directive 65/65, as amended, in respect of a medicinal product which is essentially similar to one that has been authorised for not less than six or ten years in the Community, and is marketed in the member state in which the application is made. As is apparent from the detailed formulation of these questions it was possible to take four different views as to the correct answers to them.

The fourth question (which finds some reflection in the approach taken to changes of great therapeutic significance by the UK Government) was whether any difference was made to the answers to the second and third questions according to whether the original or abridged applications for marketing authorisations were made before the date of entry into force of Regulation 541/95.

The fifth question involved the interesting issue of whether art. 4(2).8(a)(iii) was invalid because it conflicted with the need to protect innovation and/or one of the general principles of Community law. Provisions in Community legislation may be invalid if they conflict with fundamental principles of Community law.

The ECJ found that a medicinal product might be essentially similar to an earlier medicinal product, even though it had different indications and dosages.

\section{JUDGMENT OF THE ECJ}

A more detailed account of the court's judgment is given below.

\section{Answer to Question 1}

The court somewhat controversially made reference to a declaration recorded in the minutes of the Council on the occasion of the adoption of Directive $87 / 21$ for the purpose of interpreting the meaning of the concept of an 'essentially similar medical product'. Despite the court's attempt to distinguish these cases it seems somewhat difficult to reconcile this approach with its statements in $R v$ Immigration Appeal Tribunal, ex parte Antonissen (Case C-292/89) [1991] ECR I-745; [1993] 1 CEC 649, para. 18) and Re VAG Sverige $A B$ (Case C-329/95) [1997] ECR I-2675, para. 232) that such a declaration could not be used for the purpose of interpreting a provision unless it was referred to in the wording of the provision. According to the minutes of the relevant Council meeting, the criteria determining the concept of essential similarity between medicinal products are that they have the same quantitative and qualitative composition in terms of active principles, and the same pharmaceutical form, and where necessary bioequivalence of the two products has been established by appropriate bioavailability studies.

The court pointed out that it followed from the latest edition of the Commission's Rules governing medicinal products in the European Union that a medicinal product which satisfied the three criteria mentioned above might nevertheless raise questions of safety with regard to its excipients (additives, consisting of neutral or inert substances). In such an event the medicinal product could not be regarded as essentially similar to an original medicinal product where it satisfied the three criteria laid out in the minute of the Council. The position was the same where a medical product satisfied the three criteria for essential similarity, but it was apparent in the light of scientific knowledge that it differed significantly from the original product as regards efficiency or safety. The court also held that the competent authority of a member state could not disregard the three stated criteria, where it had to determine essential similarity. 
(Note the similar approach to the existence of a margin of discretion in applying the exceptions in art. 4(2).8(a)(iii) in $R_{v}$ Licensing Authority of the Department of Health, ex parte Scotia Pharmaceuticals Ltd (Case C-440/93 [1995] ECR I-2851) and $R_{v}$ The Medicines Control Agency, ex parte Smith \& Nephew Pharmaceuticals Ltd; Primecrown Ltd $v$ The Medicines Control Agency (Case C-201/94 [1996] ECR I-5819; [1997] CEC 513).

It should be noted that the court did not treat the possession of the same therapeutic indications as a relevant factor in determining essential similarity.

The court's answer to the first question was substantially the same as that given to it by Advocate General Ruiz-Jabaro in his submissions. However, there was some difference between the approach taken by the court and the Advocate General in their answers to the second question.

\section{Answer to Questions 2 and 3}

As already indicated, the court adopted the view that therapeutic indications were irrelevant for the purpose of establishing essential similarity. It held that it followed from this that an applicant for a marketing authorisation for a medicinal product that is essentially similar to a product which has been authorised for not less than six or ten years in the Community and is marketed in the member state for which the application is made is not required, under the provision at issue, to supply pharmacological, toxicological and clinical documentation, whatever may be the therapeutic indications to which the documentation for the original medicinal product relates. The court concluded that under the abridged procedure provided for in art. 4(2).8(a)(iii) of Directive 65/65, as amended, the applicant might receive marketing authorisation for all the therapeutic indications covered by the latter documentation, including those indications authorised for less than six or ten years.

There seems some reason to doubt whether the proposition in the final sentence in the above paragraph necessarily follows from that in the second one in the same paragraph. It may not be an inevitable consequence of the fact that because the later applicant does not have to supply documentation relating to pharmaceutical, toxicological and clinical tests, that pharmaceutical company is entitled to receive documentation for all the relevant therapeutic indications.

It is rather unfortunate that, because the application of point 8 (a)(iii) of the second paragraph of Directive 65/65, as amended, requires the reconciliation of different objectives, it is rather difficult to interpret. As already indicated, two of these objectives consist of the protection of public health and the prevention of unnecessary tests on humans or animals, but another one of equal importance consists of the protection of innovation and pharmacalogical research.

With the latter objective in mind, there seems considerable force in RuizJabaro AG's view that it would be advisable to apply the six or ten-year protection period to all new indications of considerable importance authorised for an original product essentially similar to a generic product. (The UK Government and the Commission adopted a rather similar approach to Ruiz-Jabaro AG.) However, it has been contended by the court that the concept of a major therapeutic indication may give rise to uncertainties. The advocate general suggested that it should be possible for the competent authorities of member states to resolve these difficulties on a case by case basis, account being taken of whether the significance of the therapeutic benefit can be proved to the European Agency for the Evaluation of Medicinal Products and whether the new indication is eligible for a patent under the Munich Convention or national law, and the scope of the tests carried out by the innovative undertaking to discover the new therapeutic indication for the original medicinal product.

It appears that the court's approach to the above problem may sometimes lead pharmaceutical companies to expend very considerable sums on innovative research without enjoying adequate protection for the end result. Although a new therapeutic indication may be eligible for a patent under the Munich Convention, or under the national law of a member state, the material required of those requesting authorisation is not fully protected. However, the use of the concept of major therapeutic innovation in the manner suggested by the advocate general might lead to occasional uncertainties.
Both the court and the advocate general adopted the view that a medicinal product which is essentially similar to a product which has been authorised for not less than six or ten years in the Community and is marketed in the member state in which the application is made may be authorised under the abridged procedure provided for in art. 4(2).8(a)(iii) of Directive 65/65 as amended, for all dosage forms, doses and dosage schedules already authorised for that product.

\section{LACK OF PROTECTION}

It appears that the court's approach to the.... problem may sometimes lead pharmaceutical companies to expend very considerable sums on innovative research without enjoying adequate protection for the end result.

\section{Answer to Question 4}

The answer of the court to the fourth question was also similar to that of the advocate general. The court found that Regulation 541/95 had no relevance whatsoever to the application of art. 4(2).8(a)(iii) of Directive 65/65, as amended. The former instrument distinguishes between minor and major variations in the terms of marketing authorisations but, as the Advocate General pointed out, a therapeutic innovation is not a relevant factor for the purpose of classifying variations as major or minor. (The Medicines Control Agency had taken the view that where a new application for marketing authorisation was required under Annex II to Regulation 541/95, marketing authorisation under the abridged procedure could not be granted in respect of additions or changes that were the subject of a first marketing authorisation until a period of ten years had elapsed since the date on which it was granted.)

\section{Answer to Question 5}

The court, which once again agreed with the advocate general, found that the validity of art. 4(2).8(a)(iii) of Directive $65 / 65$ as amended, was not affected by the principles of protection of innovation, and/or non-discrimination and/or proportionality and/or respect for property. Only the three latter principles are general principles of Community law. 
However, the second recital in the preamble to Directive $87 / 21$ mentions that innovative firms should not be put at a disadvantage by the new provisions relating to the authorisation of essentially similar medicinal products. (This principle may conflict to some extent with that in the fourth recital stating that there are reasons of public policy for not conducting repetitive tests on humans or animals without overriding cause).

The court held that no violation of the principle of non-discrimination occurred in permitting a second applicant to refer to the results of pharmacological and toxicological tests and clinical trials, the costs of which are borne by the first applicant. This was because the first and second applicants were not in comparable situations: the first applicant could show the efficacy and safety of the product only by means of tests, whilst the second applicant might merely refer to the data relating to the efficacy and safety of the original product which the first applicant had supplied without creating a risk to public health. This argument does not, with respect appear entirely convincing, because it is obvious that the second applicant is not in the same position as the first one with respect to costs.

The pharmaceutical companies had argued that the interpretation of art. 4(2).8(a)(iii) of 'Directive 65/65, as amended, would make the provision disproportionate to the aim of the abridged procedure. It is not surprising that the court refused to invoke the principle of proportionality as a ground for the invalidity of art. 4(2).8(a)(iii). The court has generally shown itself unwilling to conclude that policy choices enshrined in Community legislation are disproportionate. Thus, in a sphere in which the Community legislature is called upon to make complex assessments, judicial review of the exercise of its powers must be limited to examining whether it is vitiated by a manifest error of assessment or misuse of powers, or whether the legislature has manifestly exceeded the limits of its discretion (see Norbrook Laboratories $\mathrm{V}$ MAFF Case C-127/95 [1998] ECRI1531).

The court found that where it was clear that the medicinal product which was the subject of an abridged application under art. 4(2).8(a)(iii) was essentially similar to a product which had been authorised in the Community and was marketed in the nember state for which the application was made, the results of pharmalogical tests and clinical trials covering all the therapcutic indications authorised might be transposed to the medical product which was the subject matter of that application. Repetition of such trials was not necessary to protect public health; furthermore one of the objects of the abridged procedure was to avoid the unnecessary repetition of tests on humans or animals. The interests of innovative firms was, according to the court's (somewhat questionable) finding, sufficiently safeguarded by granting them a period of protection for their data of six or ten years from the date of the first marketing authorisation obtained in the Community for a particular product.

Thus the court found that the abridged procedure, as interpreted in the judgment, was an appropriate and reasonable means of reconciling the three aims of art. 4(2).8(a)(iii) of Directive $65 / 65$, which are made apparent in the recitals to Directive $65 / 65$ and in the recitals to the amending Directive $87 / 21$ It is clear and unsurprising in view of its earlier jurisprudence, that the court did not apply the principle of proportionality in a very rigorous manner in the present case.

Finally, the court considered the allegations of the infringement of the principles of the protection of innovation and of respect for the right of property. It found that, because the alleged infringement of the principle of protection of innovation coincided, in the present case, with the alleged infringement of the principle of respect for the right of property, these two questions could be examined together.

As was emphasised by the court, it was apparent from its case law that the exercise of the right to property may be restricted provided that the restrictions in fact correspond to objectives of general interest pursued by the Community and do not constitute disproportionate and unacceptable interference, impairing the very substance of the right guaranteed (see Firma SAM Schiffahrt GmbH v Germany (Joined Cases C-248/95 and C-249/95 [1997] ECR I-4475) and Metronome Musik GmbH v Music Point Hokamp GmbH (Case C-200/96 [1998] ECR I-1953).
The court found that art. 4(2).8(a) (iii) was in accordance with objectives of general public importance pursued by the Community. Furthermore, it held that the provision at issue could not be regarded as disproportionate or unacceptable interference impairing the very substance of the right to property because it does not appear to have rendered it virtually impossible for innovating firms to carry on their business of producing and developing medicinal products. This conclusion is unsurprising in view of the earlier jurisprudence of the court.

\section{CONCLUSIONS}

The above decision will no doubt prove somewhat burdensome for pharmaceuticals companies but, as the ECJ pointed out, it is unlikely to prevent them from carrying on business. They may also initiate a campaign seeking changes in the law. The ECJ's interpretation of the meaning of 'essentially similar' appears unexceptionable. (It may be contrasted with the interpretation given by the High Court in the unreported case of $R \quad r$ Medicines Control Agency ex parte Rhône-Poulenc, according to which essential similarity had to be determied on the basis of the therapeutic value and active agent of the drug.)

However, the ECJ's answer to the second question does not seem justified: it might have been better if a different rule had been adopted providing that new indications for the original medicinal product which are of considerable therapeutic importance and that are authorised for an original medicinal product essentially similar to a generic medicinal product should benefit from the six or ten-year protection period.

The court's approach to the third and fourth questions appears correct. Furthermore, the somewhat cautious approach which it adopted in answering the fifth question is understandable in the light of its earlier jurisprudence concerning the relevant grounds of alleged invalidity.

\section{Frank Wooldridge}

University of Notre Dame, London 